spiritus which, however, is not of the supernatural tinge of the Paracelsian world but is rather a form of energy alignable with physics and chemistry. Dr. Virchow scouts the idea. Who is right, the German or the Englishman? I am, Sirs, yours faithfully,

Joseph H. Rowe, M.B. Aberd.

Cowling, Xorkshire, Oct. 11th, 1898.

\section{THE PUBLIC APPLICATION AND USES OF BACTERIOLOGY.}

To the Editors of THE LANCET.

SIRS, - In reading the interesting leading articles at pp. 882-84 of THE LANCET of Oct. 1st one cannot help feeling that their writer has, doubtless unwittingly, done much less than justice to the eminent bacteriologist who is admittedly the pioneer in this country of the practical application of bacteriology to purposes of local public health administration and commerce. I refer to Professor Delépine of Owens College, who, as long ago as 1891, assisted the Manchester Public Health Department with his special knowledge, and in 1892 suggested to Dr. Tatham an official arrangement for the bacterial examination of diphtherial products and the like. In the summer of 1893 Professor Delépine's aid was invoked in the investigation of certain choleraic cases in Manchester and in 1894 the borough of Stockport was materially assisted by his advice and skill in regard to its watersupply. During the following summer (1895) a definite arrangement was entered into between Professor Delépine and the corporation of the last-mentioned town for the systematic bacterial examination of doubtful diphtheria cases. A little later a similar arrangement was made by Manchester and more recently by most of the other large Lancashire towns, and at the present moment Professor Delépine is fully realising his cherished desire that his splendid laboratories at Owens College should exist, not merely for academic purposes, but for the very real benefit of suffering humanity in the district of which the college is the scientific centre. The work has been with Professor Delépine entirely a labour of love; he has ungrudgingly devoted time, money, and his great abilities to its development without one single farthing of personal remuneration. He has assisted many other towns (Liverpool, Edinburgh, Belfast, Aberdeen, \&c.) by sending them all the information they required and a complete account of his procedure, and in many public health matters on which he is specially competent to advise he is the kind and ready "guide, philosopher, and friend" of every health officer who has occasion to consult him. Surely, then, it is hardly fair that in regard to the bacteriological public health service of the country his work should be placed in a second line, so to speak, with that of cities such as Liverpool, and commercial ventures such as the Clinical Research Association, which have merely followed the lead he has so ably and modestly given them. Palmam qui meruit ferat.

I am, Sirs, yours faithfully,

Health Office, Stockport, Oct. 9th, $1898 . \quad$ CHARLES PORTER.

\section{WHAT IS "FIRST AID"?}

To the Editors of $\mathrm{TH} \mathrm{H} \mathrm{A} N \mathrm{CE} \mathrm{T}$.

SIRS,-To prevent the remedial assistance of "first aid" passing beyond its bounds and encroaching upon remedial treatment $\mathbf{I}$ have found it desirable as well as necessary to define what "first aid" really consists of. As this definition might be of use to many of your readers I herewith enclose the same. "'First aid' consists in the immediate relief of suffering and the temporary dressing of all injuries sufficient to enable the sufferer to proceed to where authoritative advice can be obtained from some qualified medical man or to remain on the spot when removal is unjustifiable until that advice can be obtained."

Under this comprehensive definition the arrest of hæmorrhage, the temporary application of splints to fractures, the first dressing of burns, and the application of antiseptic dressing to wounds would take first place. Immediate assistance would include the resuscitation of the apparently dead and the first succour requisite in cases of poisoning or fits. The immediate relief of suffering would include the giving of one dose of medicine for diarrhcea, colic, or other severe pain, as well as for shock, collapse, or temporary failure of the heart's action. No redressing of wounds or injuries nor operative interference of any kind is here included; in fact, the surgical aid is limited to what would be done by bearers at the front on a battlefield before the injured are sent to the base or station hospital for final redressing and surgically approved treatment.

I am, Sirs, yours faithfully,

Devonshire-street, w., Oct. 11th, 1898. SAMUEL OSBORN.

\section{"GAS AND AIR." \\ To the Editors of THE LANCET.}

SiRs,-I shall be very happy to show Dr. Flux my gas. apparatus-now, alas, over twenty years old-by which he need not employ any napkin over the face or touch the patient's face with any of the apparatus. I have never suggested this very old method to my colleagues, much less the public, as I do not think the fees admit such a waste of gas. It reminds me of a letter I once received from the late Mr. Clover, who was taken in (by the recommendation of the committee of the British Medical Association) to use dichloride of ethidene, in which he related that a case had cost him $30 \mathrm{~s} . \mathrm{s}$ and that out of a two guinea fee. Terb. sap.

I am, Sirs, yours faithfully,

TOM BrRD,

Instructor in the Use of Ancsthetics to Guy's Hospital. Brook-street, W., Oct. 11th, 1898.

\section{THE ETHICS OF CLUB PRACTICE. To the Editors of THE LANCET.}

SIns,-I should be glad to have an expression of your. opinion on the following case.

I have been surgeon for over thirty years to a very large friendly society and my connexion with this society has. always been most amicable till about twelve months ago. Then I was called in to see a member of the society suffering from quinsy. I saw him on the Monday morning and promised to call again on the Tuesday morning, butr. owing to stress of other work I was unable to get there and sent $m y$ assistant (M.R.C.S., L.R.C.P. Lond.) to. see the man in the afternoon. (According to the patient's. own statement the man was not seen for 26 hours.) On arrival at the house my assistant was told that the patient had called in another medical man who lived nearer. In the evening this medical man telephoned to $m$ e and I said I was quite willing he should take the case, and I remarked that to me it was a club case, but he must see he got his fees. I have since: found that the throat trouble disappeared in a day or two and then brain symptoms set in-it was thought as a result of an accident received some months previously. The medical man in attendance wished for and obtained a consultation with a surgeon in the town with a view to trephining and the patient was removed to the infirmary for operation. where he fortunately recovered without operation in a few days. But I heard nothing more of the case from the time the second practitioner was called in till a few weeks later, when the patient wrote a letter to the secretary of the society in which he complained of neglect and demanded from me payment of the second medical man's bill and the consultant's fee (amounting altogether to six guineas) and said he thought the way he was "treated was not fit for any human being "and he further complained of my sending my assistant. I refused to pay the bill and denied neglect. I consider I was under no contract to see. the man at any given time, although I promised to call in the. morning. It is impossible to work a practice on these lines. and the medical man himself must, in my opinion, be the best. judge as to the relative urgency of each particular case.

The second practitioner who was called in, in reply to $a$ note from me, writes as follows: "In answer to your letter I may say that when called to see the man S-I I found him suffering from acute tonsillitis, and in following out $\mathrm{my}$ routine practice in such cases I put him on antirheumatic treatment with a gargle of guaiac., \&c. If I remember correctly the quinsy had cleared up by the next evening; at no time was it a bad one nor did it tend to suppurate. I should say that it was a rheumatic throat pure 